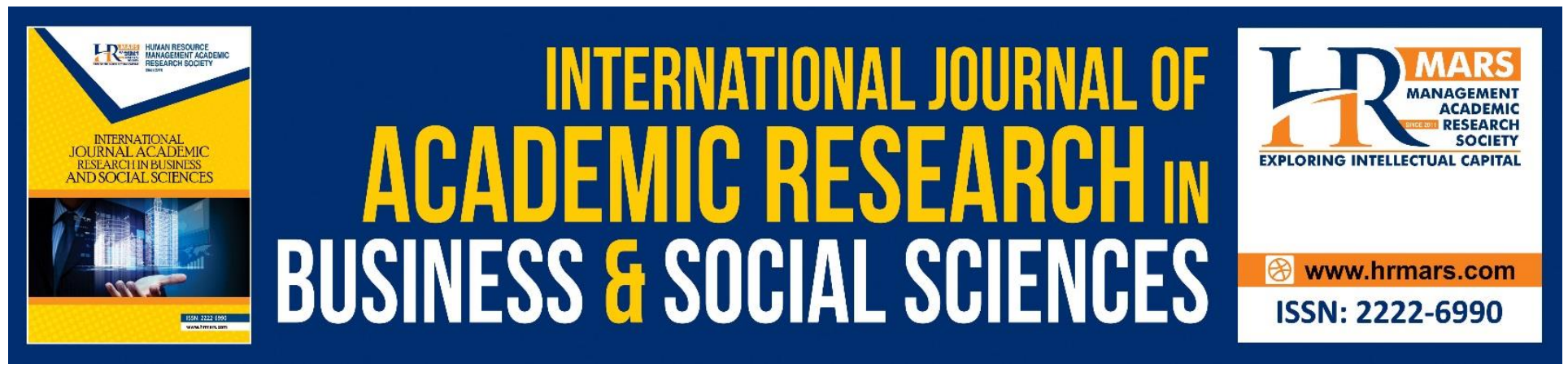

\title{
Contemplation as a Mean to Achieve Recognition of Allah
}

Abdullah M.S., Omar S.H.S., Mohammed Muneer'deen Olodo Al-Shafi'i, Mohd Hasrul Shuhari, Norislalizan Harun, Wan Hishamuddin Wan Jusoh, Aman Daima Mohd Zin

To Link this Article: http://dx.doi.org/10.6007/IJARBSS/v8-i10/4718

DOI: $10.6007 /$ IJARBSS/v8-i10/4718

Received: 27 Sept 2018, Revised: 17 Oct 2018, Accepted: 23 Oct 2018

Published Online: 30 October 2018

In-Text Citation: (Abdullah et al., 2018)

To Cite this Article: Abdullah, M. S., Omar, S. H. S., Al-Shafi'i, M. M. O., Shuhari, M. H., Harun, N., Jusoh, W. H. W., \& Zin, A. D. M. (2018). Contemplation as a Mean to Achieve Recognition of Allah. International Journal of Academic Research in Business and Social Sciences, 8(10), 119-125.

Copyright: (C) 2018 The Author(s)

Published by Human Resource Management Academic Research Society (www.hrmars.com)

This article is published under the Creative Commons Attribution (CC BY 4.0) license. Anyone may reproduce, distribute, translate and create derivative works of this article (for both commercial and non-commercial purposes), subject to full attribution to the original publication and authors. The full terms of this license may be seen at: http://creativecommons.org/licences/by/4.0/legalcode

Vol. 8, No. 10, 2018, Pg. 119 - 125

http://hrmars.com/index.php/pages/detail/IJARBSS

JOURNAL HOMEPAGE

Full Terms \& Conditions of access and use can be found at http://hrmars.com/index.php/pages/detail/publication-ethics 


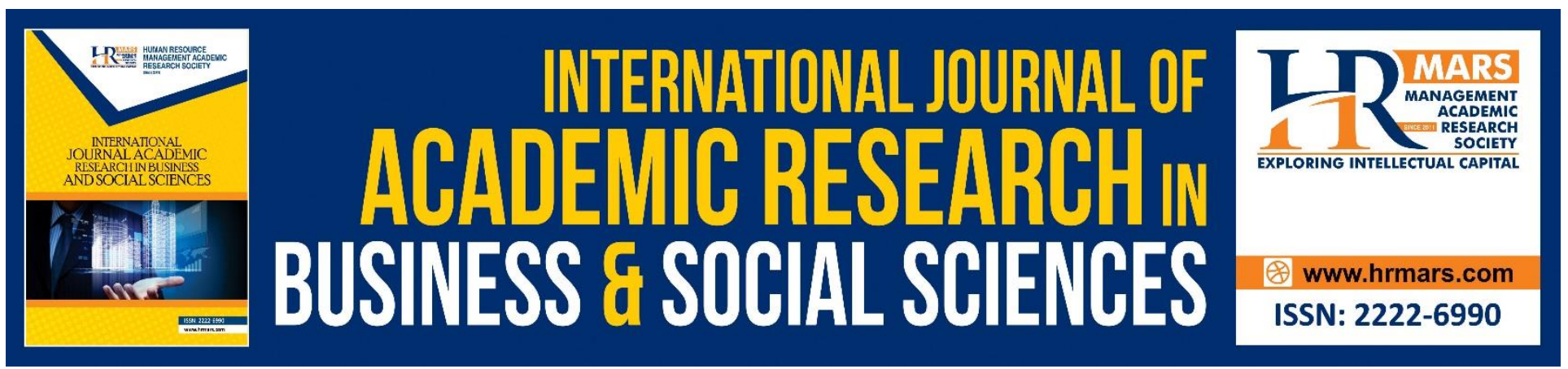

\title{
Contemplation as a Mean to Achieve Recognition of Allah
}

\author{
Abdullah M.S. ${ }^{1}$, Omar S.H.S..$^{1^{*}}$, Mohammed Muneer'deen Olodo Al- \\ Shafi'i ${ }^{1}$, Mohd Hasrul Shuhari ${ }^{1}$, Norislalizan Harun ${ }^{2}$, Wan \\ Hishamuddin Wan Jusoh ${ }^{1}$, Aman Daima Mohd Zin ${ }^{1}$ \\ ${ }^{1}$ Department of Usuluddin, Faculty of Islamic Contemporary Studies (FKI), \\ Universiti Sultan Zainal Abidin (UniSZA), Gong Badak Campus, \\ 21300 Kuala Nerus, Terengganu, Malaysia. \\ ${ }^{2}$ Sekolah Menengah Kebangsaan Tengku Mizan Zainal Abidin (STEMZA), \\ Kuala Terengganu.
}

\begin{abstract}
Al-tafakkur is an important practice of using contemplative techniques, to analyze the events of Allah's creatures, to gain confidence in everything related to ma'rifah Allah in tasawwuf. A believer in Allah increases in his faith in Allah and piety through insightful and hearty contemplations. In addition, al-tafakkur is one of the ways to remembering Allah and the hereafter, to obtain patience, peace, and tranquility. The study is an analytical study based on library resources. The study finds that al-tafakkur is an important element of tasawwuf, an essential foundation that one needs to increase in ma'rifah Allah. This is because ma'rifah Allah is applied in the discipline of tasawwuf to aim for the existence of faith and piety of Allah s.w.t, which is the main pillar in the creed of $A h / a l-$ Sunnah wa al-Jama'ah. Without iman (faith) and taqwa (piety), the Aqidah is believed to be unstable and unable to guide to the perfection of obedience to Allah. Therefore, it is worth noting that altafakkur is not merely a practice that refers to the contemplation and analysis of an incident of God's creatures; it is a special and obligatory practice in achieving ma'rifah Allah and His love as the most important part of life.
\end{abstract}

Keywords: Tafakkur, Ma'rifah Allah, Tasawuf, Iman, Taqwa

\section{INTRODUCTION}

Al-Tafakkur is an important practice, and it is identified as one of the methods of approaching Allah s.w.t, through the reflection on Allah signs. The development of Sufis order is in line with the teachings of aqidah, and fiqh conforms with the knowledge of the leaders of mu 'tabar 'ulama in their respective fields. 
INTERNATIONAL JOURNAL OF ACADEMIC RESEARCH IN BUSINESS AND SOCIAL SCIENCES

Vol. 8, No. 10, Oct. 2018, E-ISSN: 2222-6990 @ 2018 HRMARS

Nowadays, many people study Sufis order because it is one of the ways to make faith and piety of a believer grow and become intact. This brief paper discusses the concept of al-Tafakkur in enhancing the ma'rifah Allah by increasing in faith and piety in Him. He said: "think twice a year ahead". This means that the engagement in al-Tafakkur is far more beneficial than worship to Allah alone.

\section{DEFINITION OF AL-TAFAKKUR}

Al-Tafakkur stems from the basic word 'fakkara', meaning 'he thought'. It is reflection; reflection and thinking about something. In is conceptually an act of thinking about, and remembering, Allah as a reflection of His creation in heaven and on earth in its entirety.

\section{INSTANCES OF AL-TAFAKKUR IN THE QURAN}

The most important point is to read the Quran and to understand the meaning of each of its verses by meditating on its contents and meaning thoroughly. The Quran enjoins people to contemplate, as it produces peace of mind and tranquility. Allah s.w.t says:

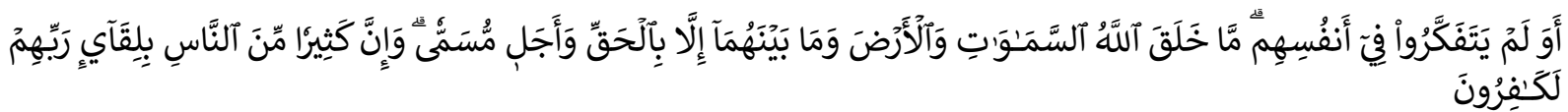

Do they not contemplate within themselves? Allah has not created the heavens and the earth and what is between them except in truth and for a specified term. And indeed, many of the people, in [the matter of] the meeting with their Lord, are disbelievers (Surah al-Rum: 8).

\section{SUFI (ASCETICS) AND TAFAKKUR PRACTICE}

As the phrase goes of Imam al-Shafi'i, in al-Munqidh min al-Dalal of al-Ghazali (1999), "fight against the lust of your mouth, and face the weird questions with contemplation", anyone who lives and faces various problems should hasten to meditation, particularly concerning the hereafter. According to al-Ghazali (2011), a meditating heart is easy to become aware and firm in the belief that affairs in the hereafter are the main thing, and thus places full hope on Allah s.w.t as the Helper and Solution to all the problems faced.

\section{AL-TAFAKKUR AS A CHARACTERISTIC FEATURE OF ULU AL-ALBAB}

It is clearly clarified in the Qur'an that ulu al-Albab (those endowed with consummate intellect) are those who meditate always through tafakkur to arrive at the higher level of tazakkur (the presence of something which is remembered and known in the heart). Allah s.w.t says:



"In the creation of the heavens and the earth, and in the alternation of the night and the day there are signs for men of understanding; those who mention and remember Allah while they are standing and sitting and when they lie in wait, and they reflect on the creation of the 
INTERNATIONAL JOURNAL OF ACADEMIC RESEARCH IN BUSINESS AND SOCIAL SCIENCES

Vol. 8, No. 10, Oct. 2018, E-ISSN: 2222-6990 ㄷ 2018 HRMARS

heavens and the earth, saying: "Our Lord! Thou hath not made these things in vain, Glory be to Thee, then Guard us from the Penalty of the Blaze."

(Ali ‘Imran: 190).

The above verse explains that the desired tafakkur is a matter beneficial to the muzakkir, to be submissive, obedient, and dedicated to His Creator (Allah s.w.t) (IbnKathir, 1990). But the believers are forbidden to meditate on the essence of Allah s.w.t, as responded by Imam Malik bin Anas when asked about how Allah s.w.t resides (istiwa') on the Throne:

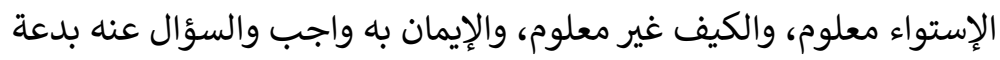
al-Istiwa (settlement on the Throne) is known, but how it is unknown, believing it is obligatory, and asking about it is innovation.

\section{THE OBJECTIVES OF MA'RIFAH ALLAH FROM THE SUFI PERCEPTION}

Al-Ghazali (2011) mentions:

$$
\text { لا تصح العبادة إلا بعد معرفة المعبود }
$$

An act of worshipping is not authorized until after ma'rifah Allah (the recognition of Allah).

According to Sheikh Abu Ali al-Daqqaq, one of the signs of ma'rifah is the emergence of Allah's blessings. Whoever increases his/her blessing will increase his/her ma'rifah. He further explains that interpretation brings peace to the heart, as knowledge brings peace ('Ajibah, 2009).

In Tanwir al-Qulub, al-Kurdi (2002) says: "So it is for the intellectual to deploy all his abilities in pursuing ma'rifah without procrastinating it. Do not delay in it, for when death comes before it, the blindness of ignorance comes over, until there is no way to see the basirah. Allah s.w.t says:

"Whoever is blind in the world, then in the hereafter will be more blind and lost way"

(al-Isra': 72)

Sheikh Amin al-Kurdi also says:

Know that self-realization is a very important matter for every person, for whoever knows himself would know his Rabb, the more you know, the more you know Allah Almighty, the Powerful and the Eternal. Whoever is stupid towards himself is stupid also against his Alah s.w.t.

According to the Sufis, ma'rifah Allah is the nature of people who know the names and attributes of Allah. It is to submit to Allah by obeying all orders and performing all instructions. And at the same time, the 'Arif bi Allah should able to abandon the abominable and prohibited traits in 
shari'ah, always remembering Allah s.w.t so that he loves for Allah and Allah loves him. Allah s.w.t in turn will grant him guidance so that he would not be influenced by various other elements that can turn himself away from the remembrance of Allah s.w.t. (Omar et. al. 2017).

With Allah's guidance that causes all acts and behavior to be clean and not mixed with evil, every movement is associated with Allah and His pleasure, which is an indefinite gift. Such guidance is the ma'rifah, and the one who has ma'rifah is referred to as al-Arif, the singular form of al-'Arifin. Abu Zakaryyah al-Ansari says that ma'rifah Allah is the knowledge that brings one to the absolute level of belief in Allah and His Oneness (al-Kalabadzi, 2001).

Sufis do not refer to everyone who has knowledge as al-'Arif, but they refer to as al-'Arif those who possess the knowledge related to Allah, the thought that everything Allah created is a proof of His existence, the attributes of perfection and beauty (Omar et. al. 2017).

Ibn'Atai'llah also speaks on the meaning of ma'rifah, he says ma'rifah is knowledge of the substance or nature that is in line with the Islamic tenets, based on the Qur'an and al-Sunnah. Ma'rifah Allah is among a preferred knowledge because it is a means to recognize the weird and incomparable substance among creatures, for 'وَلَمَ يَكُن لَّهُ، كُفْوًا أَحَحُدُ i.e -And no one is like Him ('Ajibah, 2009).

However, Allah still requires every creature to recognize Him by knowing the nature of the substance of Allah and His attributes. With ma'rifah Allah the wise continues to increase, the more the increase in ma'rifah Allah the closer he is to Allah s.w.t.

Zinnun al-Misri was asked regarding how one could recognize one's Lord, and he replied saying: "I know my Lord with the gift of my Lord, otherwise without His gift I will never know my Lord" (alQushayri, 1989). A distinguished Sufi scholar, Ibn Atai'illah divides ma'rifah Allah into two parts: i) the general Ma'rifah is to know Allah, to execute the compulsory demands of Allah, and to know Him through His knowledge related to divine issues; and ii) the specific ma'rifah Allah is to recognize Allah as the Lord of all beings. So, the one who is wise and discerning is the one who knows the substance of Allah, attributes and $a f^{\prime} a l$ through intermediation of the worship that Allah has given to the person whom He wants ('Ajibah, 2009).

A pious person recognizes his Lord with His guidance, even though the ordinary beliefs built on the divine knowledge. Imam al-Ghazali once said that a human-being can recognize his Lord through his senses if he is chosen by Allah. The highest recognition is the recognition of the divine grace. Therefore, ma'rifah Allah cannot be achieved unless by Allah's wills, like the prophets and the gnostic (Siddiq) who really know their Lord (Isa, 2005).

According to al-Ghazali (2011), the special ma'rifah Allah is the desire to know the substance, the attributes of Allah, reject all the deficiencies, and set the nature of perfection for Allah. Thus, $m a^{\prime}$ rifah Allah must be achieved by everyone, to fulfill the requirements of the Qur'an, the Sunah, and the consensus of the scholars. Imam al-Ghazali divided the narratives into two parts; the substance and the nature. 
Ma'rifah substance is a person's knowledge of Allah s.w.t, that Allah exists with various qualities of perfection, such as the attributes. He begets not nor was He begotten, and nothing is similar to him. Ma'rifah of the nature is the knowledge that Allah s.w.t is the Living, the Almighty, the All Knowing, the All-Powerful, the Hearing, the Seer, and other traits of perfection possessed by Allah s.w.t. AlGhazali adds that people who really know Allah, their heart always remember and look up to Allah s.w.t. A sign of ma'rifah Allah is deep fear of Allah; whoever increases his character to Allah will increase in his fear of Allah (al-Qushayri ,1989; Omar et. al. 2017).

Here it is possible to denounce the claims of some people who say that when we have been acquainted with God we no longer need to worship him. This indictment is an indictment of evil desire for temporary pleasure. Another scholar divides nature into two kinds; ma'rifah of the truth (ma'rifah $a l-H a q)$, and ma'rifah of the essence (the essence of the fact).

\section{THE INFLUENCE OF AL-TAFAKKUR IN ACHUEVUNG MA'RIFAH ALLAH}

Al-Tafakkur is remembering Allah s.w.t in silence, which softens the heart and draws it closer to Allah s.w.t. Al-Tafakkur leads to al-Tazakkur later. In his Ihya' 'ulum al-Din, al-Ghazali (2011) directs that a Muslim should think then evaluate on every activity, for example, his verbal confrontation, cursing, lying, purifying, laughing at others, disputes, joking and plunging into what is unimportant, and many others.

Hamka (2007), in his book, affirms that the "tongue represents our inner-self (the heart)". We should therefore handle our tongue with tafakkur. Al-Jahiz says: "the best of speech is the one that is brief, if it is worthwhile to speak, make it brief". Ibn al-Jawzi in his book, Shaid al-Khatir, writes: "the person who thinks of the end of life will certainly be vigilant, and the person who believes in the length of the journey will certainly be prepared for it". Finally, those who have ma'rifah Allah have the real piety and faith with absolute obedience to Allah s.w.t. (al-Zahabi, 1985).

\section{CONCLUSION}

Al-Tafakur is a ritual in silence to increase knowledge and good deeds. It is an extraordinary practice that can enhance the charity of the worship and strengthen the relationship with Allah as well as strengthen our intrapersonal and interpersonal relationship. It is the key to all the goodness; forming all the cognitive activities of a believer through feeling the existence of Allah s.w.t, remembrance of His attributes, and sensing His greatness and perfection (jamal). By meditating and understanding, the wisdom contained in the wonders of creations and creatures, and the life in the hereafter, softens the heart for the steadfastness of faith and piety of muttaqin in enhancing the achievement of ma'rifah Allah. This study finds that the increase of ma'rifah Allah for the spirituality of every Muslim individual is based on the practice of al-Tafakkur, and the sincerity of increasing knowledge and practice of faith and taqwa as a source of strengthening identity. 
INTERNATIONAL JOURNAL OF ACADEMIC RESEARCH IN BUSINESS AND SOCIAL SCIENCES

Vol. 8, No. 10, Oct. 2018, E-ISSN: 2222-6990 ㄷ 2018 HRMARS

\section{ACKNOWLEDGEMENT}

Special appreciations to the Research Management, Innovation \& Commercialization (RMIC), Universiti Sultan Zainal Abidin (UniSZA) \& the Faculty of Islamic Contemporary Studies (FKI, UniSZA) for sponsoring the project.

\section{Correspondence Author}

\section{Omar S.H.S.}

Department of Usuluddin, Faculty of Islamic Contemporary Studies (FKI), Universiti Sultan Zainal Abidin (UniSZA), Gong Badak Campus,

21300 Kuala Nerus, Terengganu, Malaysia.

Email: sylutfi@unisza.edu.my

\section{References}

'Ajibah, A. A. (2009). 'Iqaz al-Himam fi sharh al-Hikam. Beirut: Dar al-Kutub al-'Ilmiyyah.

Al-Ghazali, M. M. M. (2011). Ihya' 'ulum al-Din. Jeddah: Dar al-Minhaj.

Al-Ghazali, M. M. M. (1999). al-Munqidh min al-Dalal. Beirut: Dar al-Fikr.

Hamka. (2007). Tasawwuf Moden. Jakarta.

IbnKathir. (1990). Al-Bidayah wa al-Nihayah. Beirut: Dar al-Fikr.

Isa, A. Q. (2005). Haqaiq 'an al-Tasawwuf. Syria: Dar al-'Irfan.

Al-Kalabadzi, A. M. (2001). Al-Ta'aruf li mazhab ahl al-Tasawuf. Ahmad Shams al-Din (ed.). Beirut: Dar al-Kutub al-'Ilmiyyah.

Al-Kurdi, M. A. (2002). Tanwir al-Qulub Fi Mu'amalah al- 'Allam al-Ghuyub. Beirut: Dar al-Kutub al'Ilmiyyah.

Omar, S. H. S., Faisal, M. N., Fadzli Adam, N. A., Rahimah, E., Othman, M. S., \& Abdullah, S. (2017). Nature of Af'al According to Imam Al-Qushayri in the Book "At-Tahbir Fi At-Tazkir". International Journal of Academic Research in Business and Social Sciences, 7(8), 258-262.

DOI: 10.6007/IJARBSS/v7-i8/3226 URL: http://dx.doi.org/10.6007/IJARBSS/v7-i8/3226

Omar S.H.S., Rahimah E., Fadzli Adam, Othman, M.S., Basri I., Engku Ibrahim E. W. Z., Mohd Safri A., Baru R. , Mohamad Zaidin Mohamad and Suhaibah O. (2017). Techniques of Practicing Muraqaba by Sufis in Malay Archipelago. International Journal of Academic Research in Business and Social Sciences, 7(5), 347-357. DOI: 10.6007/IJARBSS/v7-i5/2973 URL: http://dx.doi.org/10.6007/IJARBSS/v7-i5/2973

Omar S.H.S., Fadzli, A., Baru, R., Norhashimah, Y. (2017). Tok Ku Paloh's manual on sufi practices in Ma'arij Al-Lahfan Li Al-Taraqqi Ila Haqaiq Al-'irfan. Pertanika Journal of Social Sciences and Humanities 25 (Special Issue), pp. 1-11.

Al-Qushayri, A. Q. (1989). Al-Risalah al-Qushairiyyah. Abd al-Halim Mahmud \& Mahmud al-Sharif (eds.). Cairo: Dar al-Sha'b.

Al-Zahabi, M. H. (1985). Al-Tafsir wa al-Mufassirin. Cairo: Maktabah Wahbah. 